population are sustained for the rest of this century, but at a huge cost - the complete loss of all the natural ecosystems of the world. Most of us, living in cities and insulated from the natural environment, would barely notice until it was too late to do anything about it. This is what many politicians, economists and industrialists seem to want - their mantra of unceasing economic growth implies that we should take for ourselves all Gaia's resources and squeeze from them the maximum shortterm gain, leaving nothing for the future.

Following this vision, we will need to transform the entire planet into a factory farm to feed our 10 billion or 15 billion mouths. There will be no room on this giant spherical feedlot for anything but ourselves and our half-dozen species of domestic plants and animals. Gaia, the natural Earth system, will have disappeared. As for the underpinning biogeochemical cycles, the best we can hope is that we can manage them ourselves, taking over the heavy responsibility for keeping Earth habitable, which Gaia once did for us automatically.

The more likely outcome is that we would barely manage them at all. In that case, we would face a sequence of global environmental crises and a steady degradation of the planetary environment that would eventually kill just as many of us as a sudden collapse. Given that, perhaps we had better hope that Lovelock is right, and Gaia does for us - or most of us before we do for her.

Andrew Watson is a professor at the School of Environmental Sciences, University of East Anglia, Norwich NR4 7TJ, UK.

e-mail:a.watson@uea.ac.uk

\section{Watch Oliver Morton's interview with James} Lovelock at www.nature.com/nature/videoarchive.

\title{
Pursuing the infinite
}

\author{
Naming Infinity: A True Story of Religious \\ Mysticism and Mathematical Creativity \\ by Loren Graham and Jean-Michel Kantor \\ Belknap/Harvard University Press: 2009. \\ 256 pp. $\$ 25.95$, £19.95
}

Religious mystics have a long history of borrowing from mathematics. It is less common for mathematicians to draw on religion. In Naming Infinity, historian of science Loren Graham and mathematician Jean-Michel Kantor argue that an esoteric Christian sect contributed to advances in set theory in Russia in the first decades of the twentieth century. In pursuing their claim, they reveal a much larger drama: the flourishing of mathematics under the repression of the early Soviet regime.

Graham and Kantor begin in 1913, when the Imperial Russian Navy stormed a monastery on a Greek peninsula where a sect of Russian Orthodox monks had fled to pursue a mystical practice known as name worshipping. Holding the heretical view that God comes into existence when named, these monks believed that repeating the name of Jesus while controlling their breath and heartbeat would bring them closer to the infinite. Their persecution at the hands of the Tsar in the ensuing years aroused the sympathy of a number of Russian intellectuals. Among them was a handful of mathematicians in Moscow who, working in the young field of set theory, also found themselves dealing with the infinite.

These Russian mathematicians had been racing their French colleagues to take the measure of infinite sets of real numbers. In 1891 the German mathematician Georg Cantor made a crucial advance when he proved

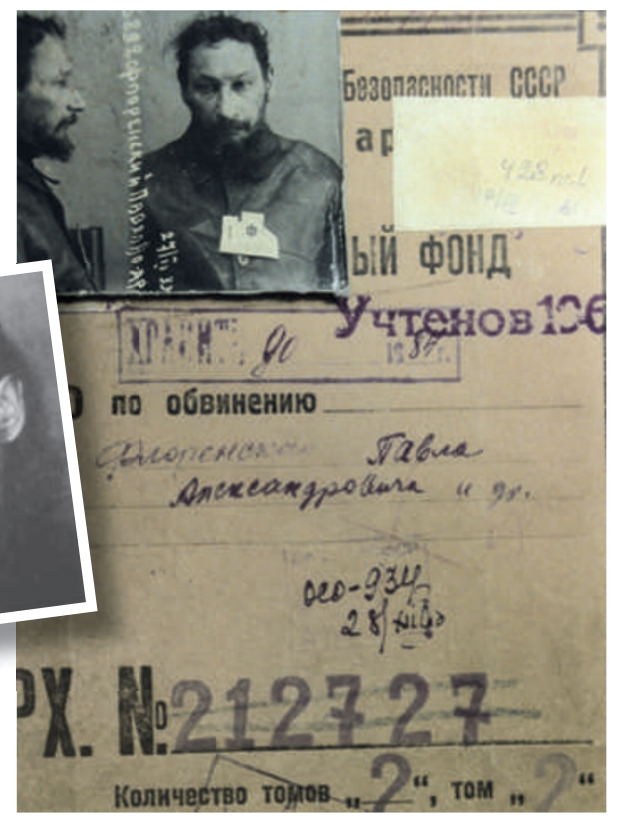

Secret-police archives document the execution of mathematician Pavel Florensky by the Soviet regime. that some infinite sets were larger than others. A group of French mathematicians at the turn of the century - including Emile Borel, Henri Lebesgue and René Baire - were searching for a systematic way to determine the size of these infinite sets. This aroused the scepticism of colleagues such as Henri Poincaré, who claimed that Cantor's hierarchy of infinities had "a whiff of form without matter, which is repugnant to the French spirit". According to the authors, the French researchers found themselves at the edge of an "intellectual abyss" where, "under the influence of their ultra-rationalistic traditions, they lost their nerve" and abandoned their work.

The situation was different in Moscow, where the Russian mathematicians took up the same problems with zeal and eventually resolved them, advancing the far-reaching field of measure theory and launching descriptive set theory. Graham and Kantor argue that the spiritual views of these mathematicians were crucial to their scholarly work. That there were ties between some of the mathematicians and the heretical sect is not in doubt. The geometer Dmitri Egorov believed in name worshipping. His student Pavel Florensky, a mathematician turned theologian, held that the 'set of all sets' might be God himself. The eminent mathematician Nikolai Luzin was privately sympathetic to the sect.

None of this illuminates a substantive connection between the ideas of the monks and the mathematicians. These Russian scholars did push forward where the French would not, so it is reasonable to ask whether their religion gave them an edge: did their belief that both God and sets could be named into existence help them deal more creatively with the infinite? The authors do not settle this question, and never fully explain why the work of the Russians should have required a belief in name worshipping as opposed to another spiritual belief. In the end, they backpedal to say they are "not claiming a unique or necessary relationship" between mysticism and mathematics but are merely saying that the heresy of name worshipping "played a role in their conceptions". They don't, however, say what that role was.

Whatever their ties, the mathematicians and the heretics suffered similar fates under the Soviet regime. For a time both escaped the worst treatment. The name-worshippers hid in the shadows as Vladimir Lenin went after the mainstream Orthodox church. Mathematicians survived longer than other academics because, unlike physicists or chemists, they did not need special equipment, and unlike historians or philosophers, 
their findings did not immediately fall foul of Soviet dogma.

Eventually the Stalinist state caught up with everyone. Egorov was detained in 1930 for "mixing mathematics and religion" and died in prison. Florensky confessed under torture and was sent to the Gulag, where he studied permafrost and seaweed before his execution in 1937. The case of Luzin is a miraculous exception. In 1936 he was accused of collaborating with foreigners by the Marxist mathematician Ernst Kolman, who proclaimed, "Soviet science will rip away your mask!” He was saved by a letter to Joseph Stalin from the physicist Peter Kapista, who argued that Luzin might yet be useful to the government. It is not clear why Stalin listened, but his whim ensured the future of a discipline.

It will be hard for the uninitiated to follow Naming Infinity, owing to the book's uneven exposition and narrow biographical focus. The connection between mathematics and mysticism is tenuous. The real drama appears around the edges, as the researchers survive famine, repression and war long enough to set the direction for a century of mathematics. It is a story of the persistence of intellectual life against the wrecking tide of history.

Jascha Hoffman is a writer based in New York. e-mail: jascha@jaschahoffman.com

\section{The hidden language of cells}

\author{
How We Live and Why We Die: The Secret \\ Lives of Cells \\ by Lewis Wolpert \\ Faber and Faber: 2009. 256 pp. $£ 14.99$
}

The greatest implication of evolutionary theory is the common kinship of living things. It is expressed no better than by Henry Harris in The Birth of the Cell (Yale University Press, 2000) as "the doctrine that all plants, animals, or whatever, are composed of independent but co-operative units we call cells". And, whatever life's origin, "the universal solution to the problems confronting its further evolution was the progressive assembly of the cell".

Lewis Wolpert's latest book attempts to relate just how far that 'progressive assembly' has gone in our own evolution. And, more concretely, he asks what insights the 'cell doctrine' gives us into the processes through which, and by which, we are conceived, develop, function, mature, grow old - and die.

It is a book in a tradition, not limited to science, of explaining the visible in terms of the invisible. But however invisible the world of cells and their molecules once was, it is not now. Through scanning electron microscopy and X-ray diffraction, coupled with modern information technology, people have become acquainted with images of cells and 'living' biological molecules. We have seen what the world of the very small looks like in three dimensions and in dramatic full colour, even if that

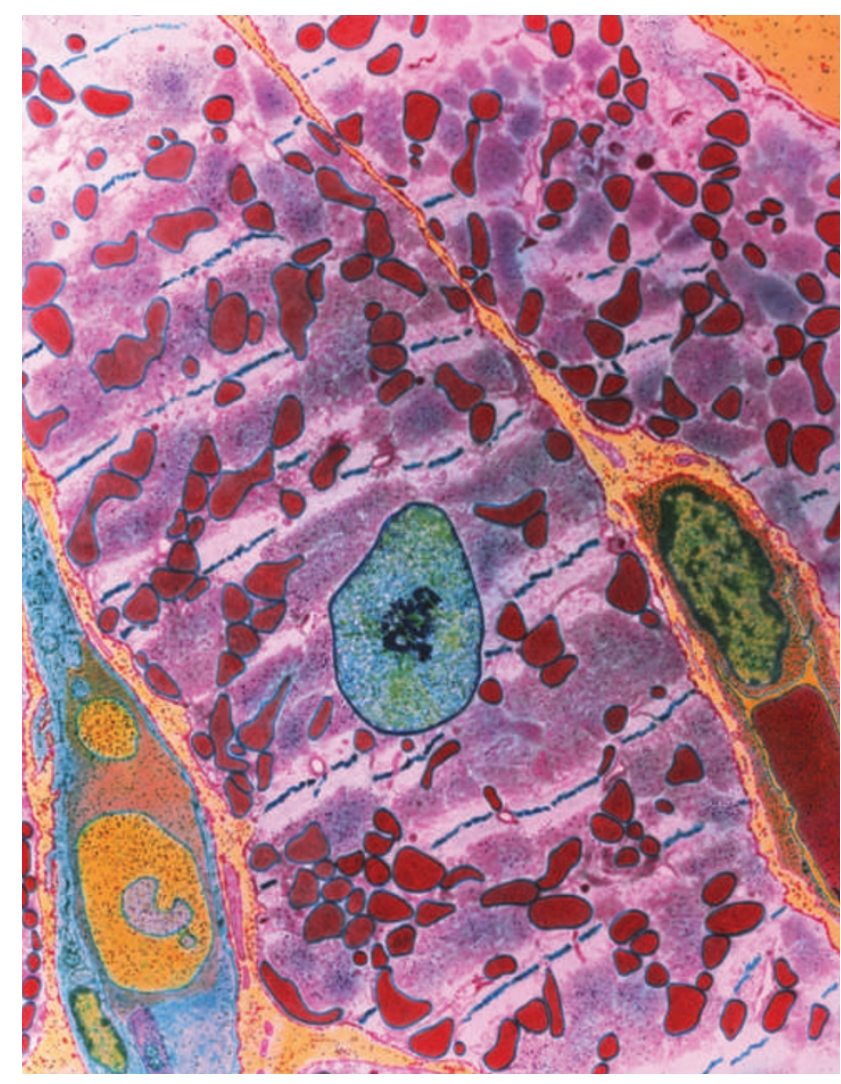

Modern microscopy reveals the many mitochondria (red) in a heart cell. 'right' size places it correctly in its - and our - physical universe.

How We Live and Why We Die is a translation from another language - biology. Years ago, Bob Burchfield, then the editor of the Oxford English Dictionary, told me that biology had more words of its own than any other area of knowledge, 60,000 or so - a greater number than most of the world's languages. Thus the scale of biological language is a measure of how biology has overwhelmed its history. The meanings of these words - the things and ideas that lie behind them - have to be negotiated into the semantic space of our everyday, more familiar world. Indeed, the book shows just how unfamiliar, eclectic, mongrel, or simply borrowed and recycled, the biological vocabulary is: $H O X$ genes, sonic hedgehog, spindle, apoptosis, aster, telomere, P53, French flag model, and so on.

Translation from biology is harder than that from a national language where much in its culture would be recognizable and the negotiation of meaning easier. It is a difficulty all too apparent in How We Live and Why We Die. And it is a difficulty emphasized by the telegraphic style Wolpert has adopted. The book says, for instance, that "Animal cells like ours generate energy from the breakdown of their food when combined with oxygen, while plants make use of sunlight". A teenage student would not get away with that. Both animal and plant cells break down 'food' using oxygen to produce energy. It is simply that plants make that food in the first place, using sunlight, whereas animals do not - they have to forage for it. Sloppy language adds to the confused picture in sentences like this: "The factory for producing energy in animal cells comprises special structures known as mitochondria". "Factories" don't produce energy, they use it. A power station is the right analogy. "Comprises" is the wrong word and "special" tells us nothing.

Rendering science into understandable everyday language without losing its point may be hard. "Language is the dress of thought," wrote Samuel Johnson. How well do the new linguistic clothes fit the ideas? The example above - only too typical of the book - shows that sometimes the answer is, badly. The author seems to have been lost for words. And regrettably, so am I.

John Galloway is at the Eastman

Dental Hospital, 256 Gray's Inn Road, London WC1X 8LD, UK. e-mail: john.galloway@uclh.nhs.uk 